\title{
Maslinic Acid, a Triterpene from Olive, Affects the Antioxidant and Mitochondrial Status of B16F10 Melanoma Cells Grown under Stressful Conditions
}

\author{
Khalida Mokhtari, ${ }^{1,2}$ Eva E. Rufino-Palomares, ${ }^{1}$ Amalia Pérez-Jiménez, ${ }^{1,3}$ \\ Fernando J. Reyes-Zurita, ${ }_{1}^{1}$ Celeny Figuera, ${ }^{4}$ Leticia García-Salguero, ${ }^{1}$ Pedro P. Medina, ${ }^{1}$ \\ Juan Peragón, ${ }^{5}$ and José A. Lupiáñez ${ }^{1}$ \\ ${ }^{1}$ Department of Biochemistry and Molecular Biology I, Faculty of Sciences, University of Granada, 18071 Granada, Spain \\ ${ }^{2}$ Department of Microbiology, Faculty of Sciences, Mohammed I University of Oujda, 60000 Oujda, Morocco \\ ${ }^{3}$ Department of $i+D+I$, Biomaslinic S.L., Polígono Industrial de Escúzar, 18130 Granada, Spain \\ ${ }^{4}$ Department of Biochemistry, Faculty of Sciences, Simón Bolivvar University of Caracas, Caracas 1080, Venezuela \\ ${ }^{5}$ Department of Experimental Biology, Biochemistry Section, Faculty of Experimental Biology, University of Jaén, 23071 Jaén, Spain
}

Correspondence should be addressed to José A. Lupiáñez; jlcara@ugr.es

Received 19 April 2015; Accepted 14 June 2015

Academic Editor: Fabio Firenzuoli

Copyright (C) 2015 Khalida Mokhtari et al. This is an open access article distributed under the Creative Commons Attribution License, which permits unrestricted use, distribution, and reproduction in any medium, provided the original work is properly cited.

\begin{abstract}
Maslinic acid (MA) is a natural compound whose structure corresponds to a pentacyclic triterpene. It is abundant in the cuticular lipid layer of olives. MA has many biological and therapeutic properties related to health, including antitumor, anti-inflammatory, antimicrobial, antiparasitic, antihypertensive, and antioxidant activities. However, no studies have been performed to understand the molecular mechanism induced by this compound in melanoma cancer. The objective of this study was to examine the effect of MA in melanoma (B16F10) cells grown in the presence or absence of fetal bovine serum (FBS). We performed cell proliferation measurements, and the reactive oxygen species (ROS) measurements using dihydrorhodamine 123 (DHR 123) and activities of catalase, glucose 6-phosphate dehydrogenase, glutathione S-transferase, and superoxide dismutase. These changes were corroborated by expression assays. FBS absence reduced cell viability decreasing $\mathrm{IC}_{50}$ values of MA. The DHR 123 data showed an increase in the ROS level in the absence of FBS. Furthermore, MA had an antioxidant effect at lower assayed levels measured as DHR and antioxidant defense. However, at higher dosages MA induced cellular damage by apoptosis as seen in the results obtained.
\end{abstract}

\section{Introduction}

Olea europaea L. is an evergreen tree widely distributed in the Mediterranean countries, where they cover 8 million ha, accounting for almost $98 \%$ of the world crop [1]. It is studied for its alimentary use (the fruits and the oil are important components in the daily diet of a large part of the world's population), whereas the leaves and seeds are important for their secondary metabolites such as terpenes group.

Maslinic acid (MA), a natural pentacyclic triterpene, has attracted much interest due to its proven pharmacologic safety and its many biological activities, such as antiviral [2], antidiabetogenic [3], anti-inflammatory [4], and antimicrobial [5] functions. More recently, some studies have shown that MA has anticancer property in different types of cancer [6-12]. Moreover, MA inhibits glycogen phosphorylase in rat liver and muscle [13-15], decreases glucose in diabetogenic mouse [16], and stimulates healthy whole animal and tissue growth [17-21]. Although a recent study showed that MA induces apoptosis in several cancer cells no such effect has been reported in melanoma cells. In particular, the involvement of MA-mediated reactive oxygen species (ROS) production in apoptotic signaling in B16F10 melanoma cells remains unknown. Oxidative stress refers to a cell's state 
characterized by excessive production of ROS and is one of the most important regulatory mechanisms for cancer [22].

To protect from high ROS levels, living organisms possess an enzymatic antioxidant that scavenges them. In a normal situation, ROS can be detrimental when produced in high amounts in the intracellular compartments and cells generally respond to ROS by upregulating antioxidants such as superoxide dismutase (SOD), catalase (CAT), glutathione peroxidase (GPx), and glutathione S-transferase (GST) that protect them by converting dangerous free radicals to harmless molecules. Glucose-6-phosphate dehydrogenase $(\mathrm{G} 6 \mathrm{PDH})$ is also involved in the antioxidant mechanism as it produces NADPH which is a direct scavenger of free radicals [23]. ROS and cellular oxidant stress have long been associated with cancer processes [24, 25]. In cancer cells, oxidative stress has been linked to the regulation of numerous cellular processes including DNA damage, proliferation, cellular adhesion, and migration and the regulation of cell survival or death [26].

Previous studies have shown that ROS induce depolarization of the mitochondrial-membrane potential as well as release of cytochrome $\mathrm{c}$ from the mitochondria into the cytosol. This increase triggers the activation of caspase- 9 and initiates the caspase cascade, which induces apoptosis in tumor cells $[6,7,27]$. Recently, many reports have shown that components from plants such as celastrol $[28,29]$ and jacaranone [30] induce apoptosis of melanoma cells through production of ROS.

The aim of this study is to observe the effect of MA in the absence of fetal bovine serum (FBS) in B16F10 melanoma cells by analyzing the ROS production and the activity and expression of the main antioxidants enzymes considering that the absence of FBS during growth causes a clear situation of cellular stress.

\section{Materials and Methods}

2.1. Drug. MA was kindly provided by Biomaslinic S.L. Its molecular weight is $472.7 \mathrm{~g} / \mathrm{mol}$. Figure 1 shows the chemical structure of MA $((2 \alpha, 3 \beta)$-2,3-dihydroxyolean-12-en-28-oic acid). The extract used is a chemically pure white powder comprising $98 \% \mathrm{MA}$ and is stable when stored at $4^{\circ} \mathrm{C}$. MA was dissolved before use at $10 \mathrm{mg} / \mathrm{mL}$ in $50 \%$ DMSO and $50 \%$ PBS. Stock solution was frozen and stored at $-20^{\circ} \mathrm{C}$. For treatments, this solution was diluted in cell culture medium.

\subsection{Cell Line and Experimental Conditions. B16F10 cells} were cultured in high-glucose DMEM supplemented with $2 \mathrm{mM}$ glutamine, $10 \%$ heat-inactivated FBS, 10,000 units/mL penicillin, and $10 \mathrm{mg} / \mathrm{mL}$ streptomycin. The cell line was maintained in a humidified atmosphere with $5 \% \mathrm{CO}_{2}$ at $37^{\circ} \mathrm{C}$. Cells were passaged at preconfluent densities by the use of a solution containing $0.05 \%$ trypsin and $0.5 \mathrm{mM}$ EDTA. The B16F10 cells were seeded in the culture dishes at the desired density. After $24 \mathrm{~h}$ hours, when the cells are attached to the dish, the dishes were incubated with DMEM containing 0\% FBS or $10 \%$ FBS for $24 \mathrm{~h}$ under the conditions described for cell culture. Following that, cells were incubated with MA.

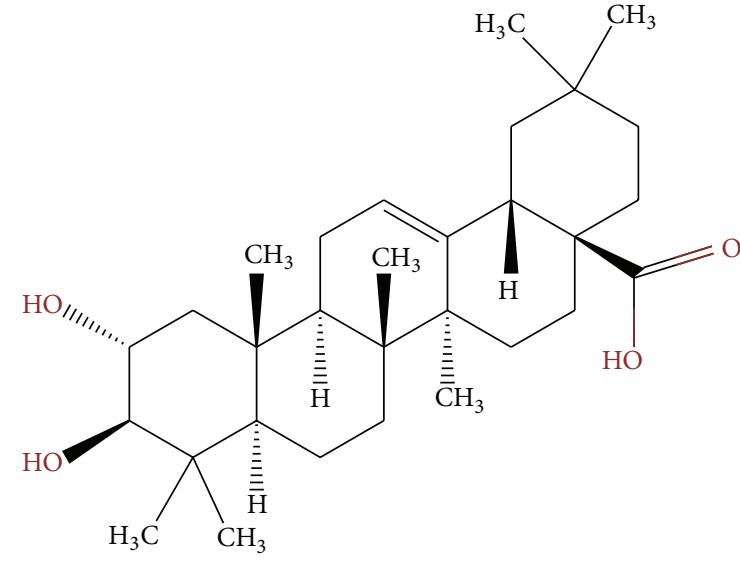

FIGURE 1: The chemical structure of maslinic acid (MA).

2.3. Cell Proliferation. The assay was performed by a variation of the method described by Mosmann [31]. Samples containing $200 \mu \mathrm{L}$ cell suspension $\left(1.5 \cdot 10^{3}\right.$ cells/well) were cultured in 96-well plates. Subsequent to the adherence of the cells within $24 \mathrm{~h}$ of incubation with and without FBS at $37^{\circ} \mathrm{C}$, different MA dilutions on a scale of $10 \mu \mathrm{g} / \mathrm{mL}$ to $100 \mu \mathrm{g} / \mathrm{mL}$ were added separately. Following incubation for $24 \mathrm{~h}$ at $37^{\circ} \mathrm{C}$ in a humidified incubator with $5 \% \mathrm{CO}_{2}$, MTT dissolved in PBS and medium at $5 \mathrm{mg} / \mathrm{mL}$ and sterile-filtered was added to all the wells at a final concentration of $0.5 \mathrm{mg} / \mathrm{mL}$. Following $2 \mathrm{~h}$ incubation, the generated formazan was dissolved with $100 \mu \mathrm{L}$ DMSO per well. The optical density was measured on an ELISA plate reader (ELISA, ELx800, Bio-Tek) at $550 \mathrm{~nm}$. Absorbance was proportional to the number of cells. The concentrations that caused $50 \%$ of inhibition of cell growth $\left(\mathrm{IC}_{50}\right)$ were calculated.

2.4. Protein Extraction. For sample preparation, cells at $70 \%$ confluence were incubated for $24 \mathrm{~h}$ without FBS and subsequently were incubated with $\mathrm{IC}_{50}, \mathrm{IC}_{50 / 2}$, and $\mathrm{IC}_{50 / 8}$ concentrations for $24 \mathrm{~h}$. Following this, the cells were washed three times with PBS, scraped off with a cell scraper (Renner), and collected in $0.5 \mathrm{~mL}$ RIPA buffer. Immediately, cells were sonicated on ice for $5 \mathrm{~min}$ and maintained by moderate shaking at $4^{\circ} \mathrm{C}$ for $1 \mathrm{~h}$. Every $15 \mathrm{~min}$, the samples were moderately shaken in a vortex. The lysates were spun in a centrifuge at $10,000 \mathrm{~g}$ at $4^{\circ} \mathrm{C}$ for $15 \mathrm{~min}$. The supernatants were used for enzyme activity and Western blot assays, and the protein concentrations were measured by BCA Protein Assay (Thermo Scientific, USA). For each experimental group, 2 replicates of the homogenates were made. Each replicate was made with 3 different cell populations.

2.5. Mitochondrial-Membrane Potential by DHR 123. Changes in the mitochondrial-membrane potential can be examined by monitoring the cell fluorescence after double staining with rhodamine 123 (Rh123) and propidium iodide (PI). Rh123 is a membrane-permeable fluorescent cationic dye that is selectively taken up by mitochondria directly proportional to the MMP (mitochondrial-membrane permeabilization). Around $4 \times 10^{5}$ cells/well were placed on 6 -well 
plates with $2 \mathrm{~mL}$ of medium without FBS and treated with cytotoxic compounds for $24 \mathrm{~h}$ at $\mathrm{IC}_{50}, \mathrm{IC}_{50 / 2}$, and $\mathrm{IC}_{50 / 8}$ concentrations. Following the treatment, the medium was removed and a fresh medium with DHR, at a final concentration of $5 \mu \mathrm{g} / \mathrm{mL}$, was added. After $30 \mathrm{~min}$ of incubation, the medium was removed and the cells were washed and resuspended in PBS with $5 \mu \mathrm{g} / \mathrm{mL}$ of PI. The intensity of fluorescence from Rh123 and PI was determined using an ACS flow cytometer (Coulter Corporation, Hialeah, FL, USA), at the excitation and emission wavelengths of $500 \mathrm{~nm}$ and $536 \mathrm{~nm}$, respectively.

2.6. Enzyme Assays. All enzyme assays were carried out at $25^{\circ} \mathrm{C}$ using a Power Wave $\mathrm{X}$ microplate scanning spectrophotometer (Bio-Tek Instruments, USA) and run in duplicate in 96-well microplates. This made it necessary to adapt all the enzymatic methods described below to the microplate reader to obtain optimal activities. Adaptation of the methods was done by scaling down the reaction mixtures to a final volume of $200 \mu \mathrm{L}$ and by adjusting both the total time for which reactions were allowed to proceed and the measurement intervals. In addition, the optimal substrate and protein concentrations for the measurement of maximal activity for each enzyme were established by preliminary assays.

The enzymatic reactions were initiated by addition of the tissue extract, except for SOD where xanthine oxidase was used. The millimolar extinction coefficients used for $\mathrm{H}_{2} \mathrm{O}_{2}$, $\mathrm{NADH} / \mathrm{NADPH}$, and DTNB [5,5-dithiobis (2-nitrobenzoic acid)] were $0.039,6.22$, and 13.6 , respectively. The assay conditions were as follows.

Superoxide dismutase (SOD; EC 1.15.1.1) activity was measured by the ferricytochrome $c$ method using xanthine/xanthine oxidase as the source of superoxide radicals. The reaction mixture consisted of $50 \mathrm{mM}$ potassium phosphate buffer (pH 7.8), 0.1 mM EDTA, $0.1 \mathrm{mM}$ xanthine, $0.013 \mathrm{mM}$ cytochrome $\mathrm{c}$, and $0.024 \mathrm{IU} / \mathrm{mL}$ xanthine oxidase. Activity is reported in units of SOD per milligram of protein. One unit of activity was defined as the amount of enzyme necessary to produce a $50 \%$ inhibition of the ferricytochrome $c$ reduction rate [32].

Catalase (CAT; EC 1.11.1.6) activity was determined by measuring the decrease of hydrogen peroxide concentration at $240 \mathrm{~nm}$ according to Aebi [33]. The reaction mixture contained $50 \mathrm{~mm}$ potassium phosphate buffer $(\mathrm{pH} \mathrm{7.0)}$ ) and $10.6 \mathrm{mM}$ of freshly prepared $\mathrm{H}_{2} \mathrm{O}_{2}$.

Glucose-6-phosphate dehydrogenase (G6PDH; EC 1.1.1.49) activity was determined at $\mathrm{pH} 7.6$ in a medium containing $50 \mathrm{mM}$ Hepes buffer, $2 \mathrm{mM} \mathrm{MgCl}_{2}, 0.8 \mathrm{mM}$ $\mathrm{NADP}^{+}$and glucose 6-phosphate were used as substrate. The enzyme activity was determined by measuring the reduction of $\mathrm{NADP}^{+}$at $340 \mathrm{~nm}$ as previously described by Lupiañez et al. [34] and Peragón et al. [35]. The change in absorbance at $340 \mathrm{~nm}$ was recorded and, after confirmation of no exogenous activity, the reaction started by the addition of substrate.

Glutathione S-transferase (GST; EC 2.5.1.18) activity was measured according to the method described by Habig et al. [36], using 1-chloro-2,4-dinitrobenzene as a substrate.
2.7. Western Blot Analysis. Polyacrylamide gel electrophoresis under denaturing conditions (SDS-PAGE) was performed in a Mini-Protean II electrophoresis system (Bio-Rad, Richmond, USA). The cell extract were mixed with a charge buffer that contained $62.5 \mathrm{mM}$ Tris- $\mathrm{HCl}$ at $\mathrm{pH} 6.8,20 \mathrm{~g} \mathrm{~L}^{-1}$ SDS, $100 \mathrm{~mL} \mathrm{~L}^{-1}$ glycerol, $25 \mathrm{gL}^{-1} \beta$-mercaptoethanol and $0.045 \mathrm{mM}$ bromophenol blue and then heated for $5 \mathrm{~min}$ at $100^{\circ} \mathrm{C}$. Polypeptides were separated on a $12 \%$ SDSPAGE and subsequently transferred to polyvinylidene fluoride membranes with a semidry electroblotting system at $1.5 \mathrm{~mA} / \mathrm{cm}^{2}$ for $45 \mathrm{~min}$ in a medium containing $25 \mathrm{mM}$ Tris$\mathrm{HCl}, 192 \mathrm{mM}$ glycine, $200 \mathrm{~mL} \mathrm{~L}^{-1}$ methanol, and $1 \mathrm{~g} \mathrm{~L}^{-1}$ SDS. Blots were blocked for $2 \mathrm{~h}$ at room temperature with a Tris buffered solution (TBS) that contained $25 \mathrm{mM}$ Tris$\mathrm{HCl}, 100 \mathrm{mM} \mathrm{NaCl}, 2.5 \mathrm{mM} \mathrm{KCl}, \mathrm{pH} 7.6,1 \mathrm{~mL} \mathrm{~L}^{-1}$ Tween 20 , and $15 \mathrm{~g} \mathrm{~L}^{-1}$ bovine serum albumin (BSA) at $\mathrm{pH}$ 7.6. Membranes were washed with TBS containing $1 \mathrm{~mL} \mathrm{~L}^{-1}$ Tween 20 (TBS-T) for $15 \mathrm{~min}$ and later incubated with specific primary antibodies: anti-glucose 6-phosphate dehydrogenase (G6PDH) 1:1,000 (Sigma, A9521), anti-SOD 1:500 (Santa Cruz Biotechnology, sc-101523), anti-GST 1:1,000 (Santa Cruz Biotechnology, sc-374171), anti-CAT 1:1,000 (Santa Cruz Biotechnology, sc-34285), anti-G6PDH 1:5,000 (Sigma, A9521), and anti- $\alpha$-actin 1:1,000 (Sigma, A2668). Following three washes with TBS-T containing $10 \mathrm{~g} \mathrm{~L}^{-1}$ BSA (TBS-TBSA) for $10 \mathrm{~min}$, membranes were incubated with a HRP conjugated goat anti-rabbit antibody IgG or anti-mouse IgG $(1: 10,000)$. Blots were developed using the ECL-Plus Western blot detection system (GE Healthcare). The specific signals were exposed on medical film (Konica Minolta). Films were scanned with a Hewlett-Packard scanner and quantified using Multi-Gauge program (Fuji Film Europe).

2.8. Statistical Analysis. Data are shown as mean \pm the standard deviation (SD). The statistical significance of differential findings between non-FBS group and control was determined by Student's $t$-test. One-way ANOVA test was performed to determine the significance of the differences between MA concentrations. SPSS version 15.0 for Windows software package was used for statistical analysis. $P$ values smaller than 0.05 were considered statistically significant.

\section{Results and Discussion}

3.1. FBS Deprivation and Cellular Growth. We examined the effect of MA on the proliferation of B16F10 melanoma cell lines using MTT assay under the presence and absence of FBS. Several groups have studied the effects of the absence of FBS in cancer cells. However, their focus has not been on the variation of cytotoxicity of a compound but on the synchronization of the cells in a particular phase of cell cycle as it was reported that the deprivation of FBS allows arrest of cell cultures into $\mathrm{G}_{0} / \mathrm{G}_{1}$ cell cycle stage [37]. It has been shown that lower concentrations of FBS (0.5\% and $0.75 \%)$ caused a significant decrease in cellular quantity and this condition could induce DNA fragmentation and subsequent cell death [38]. Moreover, several studies have been focused on improving the composition of FBS in order to enhance 


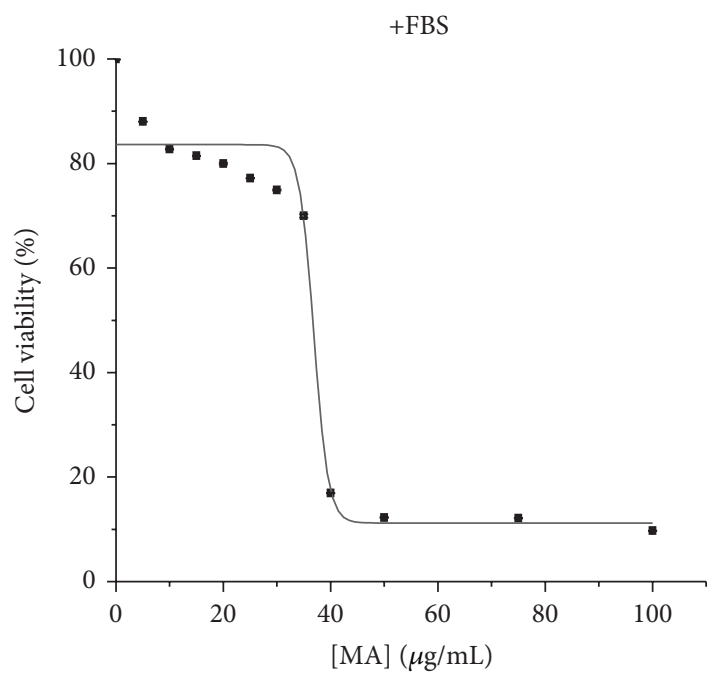

(a)

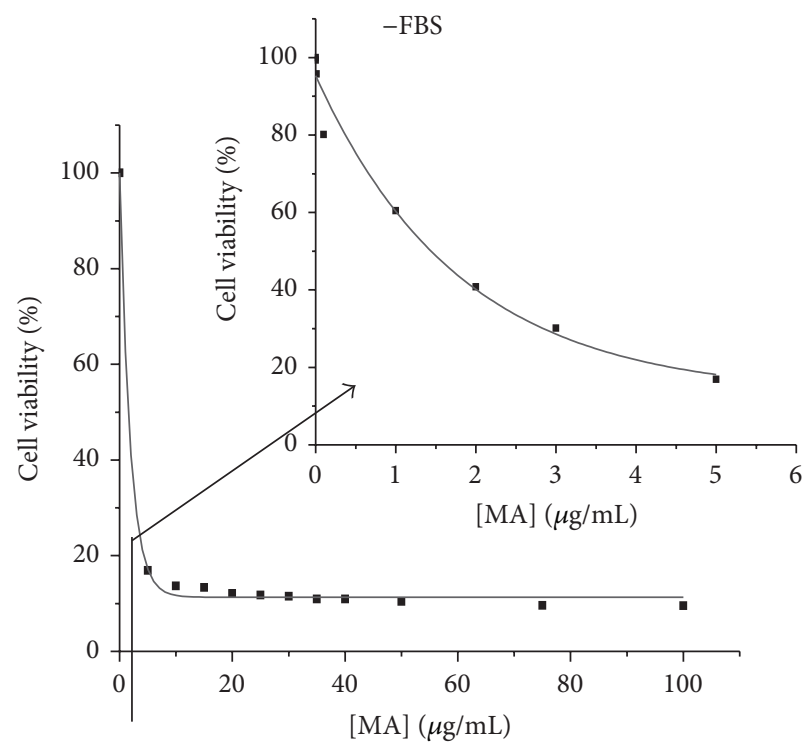

(b)

\begin{tabular}{lrccc}
\hline MA doses & \multicolumn{2}{c}{+ FBS } & \multicolumn{2}{c}{$-\mathrm{FBS}$} \\
\hline Units & $(\mu \mathrm{g} / \mathrm{mL})$ & $(\mu \mathrm{M})$ & $(\mu \mathrm{g} / \mathrm{mL})$ & $(\mu \mathrm{M})$ \\
$\mathrm{IC}_{50 / 8}$ & $4.61 \pm 0.08$ & $10.78 \pm 0.19$ & $0.19 \pm 0.01$ & $0.44 \pm 0.02$ \\
$\mathrm{IC}_{50 / 2}$ & $18.44 \pm 0.94$ & $43.11 \pm 2.20$ & $0.74 \pm 0.01$ & $1.73 \pm 0.02$ \\
$\mathrm{IC}_{50}$ & $36.88 \pm 2.45$ & $86.22 \pm 5.73$ & $1.48 \pm 0.04$ & $3.46 \pm 0.09$ \\
\hline
\end{tabular}

(c)

FIGURE 2: The effect of MA on B16F10 murine melanoma cell viability in the presence of FBS (a) and in the absence of FBS (b). MA cytotoxic doses are shown in (c). Cell proliferation was determined by MTT assay. Values are expressed as means \pm SD.

the culture cell growth; in this sense, FBS dose dependent studies have been performed [39].

Percentage of living cells (viable formazan accumulating cells) decreased in a dose dependent manner in the presence and absence of FBS. We noticed that $50 \%$ growth inhibition values $\left(\mathrm{IC}_{50}\right)$ in response to $\mathrm{MA}$ were different in media without FBS, compared to media supplemented with FBS; therefore, MA has an increased cytotoxic effect when cells do not have FBS. These results are reported in Figure 2.

MA dose, which reaches $\mathrm{IC}_{50}$ value in the culture medium supplemented with $10 \%$ of FBS, was $36.88 \mu \mathrm{g} / \mathrm{mL}(86 \mu \mathrm{M})$ and $1.48 \mu \mathrm{g} / \mathrm{mL}(3.5 \mu \mathrm{M})$ in a medium with $0 \%$ of FBS. These results indicate that MA has a cytotoxic effect with FBS in the cell culture, but this effect is higher in its absence. Our explanation of this is that absence of FBS modifies the cell homeostasis causing an increase of free radicals and therefore, MA presents a higher cytotoxic effect in the absence of FBS. An imbalance between free radicals and antioxidants results in a condition known as oxidative stress, which leads to metabolic malfunctions and damage to biological macromolecules [40].

MA cytotoxicity has been studied by other groups in several types of cancer cells and it has been shown that the MA quantity has a variable effect on the function of the type of cells and experimental conditions. For example, in HT29 cells the MA quantity that results in growth inhibition of $50 \%$ of the population is $30 \mu \mathrm{M}[8,10]$ and in Caco-2 the $\mathrm{IC}_{50}$ of $\mathrm{MA}$ is $10.82 \mu \mathrm{M}$ [7], whereas in bladder cancer the $\mathrm{IC}_{50}$ value changed according to the bladder type cell lines, the values being between 20 and $300 \mu \mathrm{M}$ [41].

3.2. Maslinic Acid Effect on Mitochondrial-Membrane Potential. DHR 123 is a ROS assay in which this compound can be oxidized intracellularly by ROS to form the positively charged fluorescent Rh123 [42] and is accumulated into the mitochondria [43]. We have performed an assay of ROS production by DHR in the absence of FBS and using three different MA levels $\left(\mathrm{IC}_{50 / 8}, \mathrm{IC}_{50 / 2}\right.$, and $\left.\mathrm{IC}_{50}\right)$ based on our cytotoxicity results. Firstly, we have shown that the absence of FBS produced an increase in ROS production due to mitochondrial disruption (Figure 3(a)). FBS composition includes proteins, growth factors, hormones, and ions [44, 45]. Cell culture without FBS forces the cell to synthesize all required compounds necessary for its normal metabolic activity. This fact involves an increase in the cellular metabolism which is reflected in a higher cellular mitochondrial activity, indirectly determined by DHR 123 assay as shown in quadrant 4 (Q4).

Our results indicated that ROS level decreased at lower concentration of MA used $\left(\mathrm{IC}_{50 / 8}\right)$. Increasing MA induced a direct increase in ROS level; hence, a dose dependent 

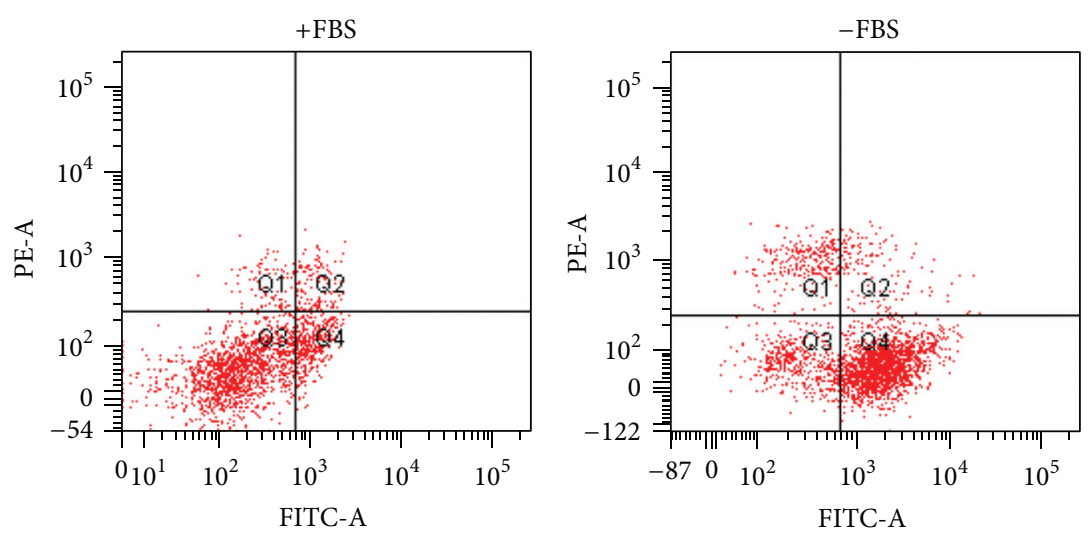

(a)

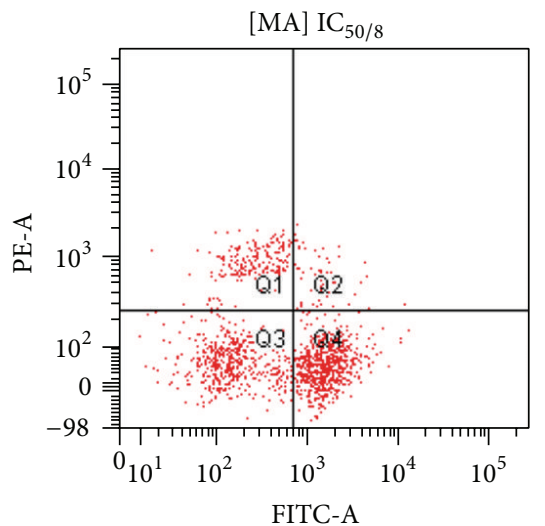

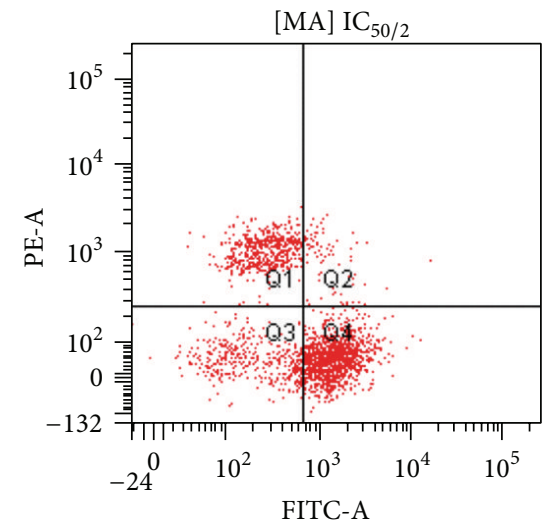

(b)

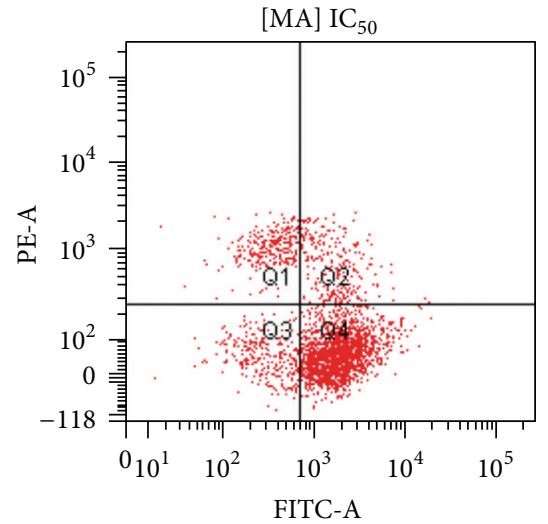

FIgURE 3: Positive fluorescent Rh123 on B16F10 cells with or without FBS (a) and after MA treatment at different dosages without FBS (b).

response was observed (Figure 3(b)). Among other properties, MA has been reported as a natural antioxidant [46-49]. In this context, the decrease in ROS level observed at MA at $\mathrm{IC}_{50 / 8}$ concentration could be attributed to its antioxidant property. On the other hand, MA induces apoptosis by activating intrinsic pathways that increase cellular ROS production [4, 48-52]. Mitochondria are the primary cellular site of ROS production and, under certain conditions, elevated mitochondrial ROS levels can serve as proapoptotic signals in cancer cells; as a result, drugs that induce ROS are receiving greater attention for their potential as chemotherapeutic agents [53]. In our previous studies, we have shown that MA induces apoptosis in cancer colon cells $[10,13,54]$.

In the present study, the observed results on ROS production at higher MA levels are not just probably due to the absence of the antioxidant effect but due to a combination of antioxidant and apoptotic properties of MA when cells are cultured without FBS. Therefore, the increased MA levels are related to the higher apoptotic capacity of triterpene as shown by the higher ROS levels determined by DHR 123 assay (Figure 3).

3.3. Antioxidant Enzymatic Response. An evaluation of the activities of the antioxidant enzymes superoxide dismutase (SOD), catalase (CAT), glucose 6-phosphate dehydrogenase
$(\mathrm{G} 6 \mathrm{PDH})$, and glutathione-S-transferase (GST) was performed under our experimental conditions (Figure 4). The results indicated that CAT, G6PDH, and SOD showed no change in their activity in the absence of FBS compared to the control with FBS, and only GST activity increased in the absence of FBS with respect to control in the presence of FBS, since this enzyme is related to detoxification of lipid peroxidation products, which are being generated under the assayed conditions.

When MA is added to the cell culture, CAT, G6PDH, and GST activities decreased below controls data. This effect was observed at all doses of MA used and in a dose dependent response pattern. However, SOD activity in the presence of MA was not affected. This variability in responses of different antioxidant enzymes may be due to linked factor combination. As previously indicated, MA induces apoptosis at higher doses. Apoptosis mechanism involves biochemical changes in the cells to achieve death. The changes observed in the first step of apoptosis imply homeostatic cellular disruption.

These alterations inhibit biosynthesis of new molecules and damaged metabolites renewal, a fact related to the low G6PDH activity observed. G6PDH is the main enzyme to produce NADPH which is essential for reductive biosynthesis and nucleic acid synthesis [55] and protects the cell against 
Catalase activity
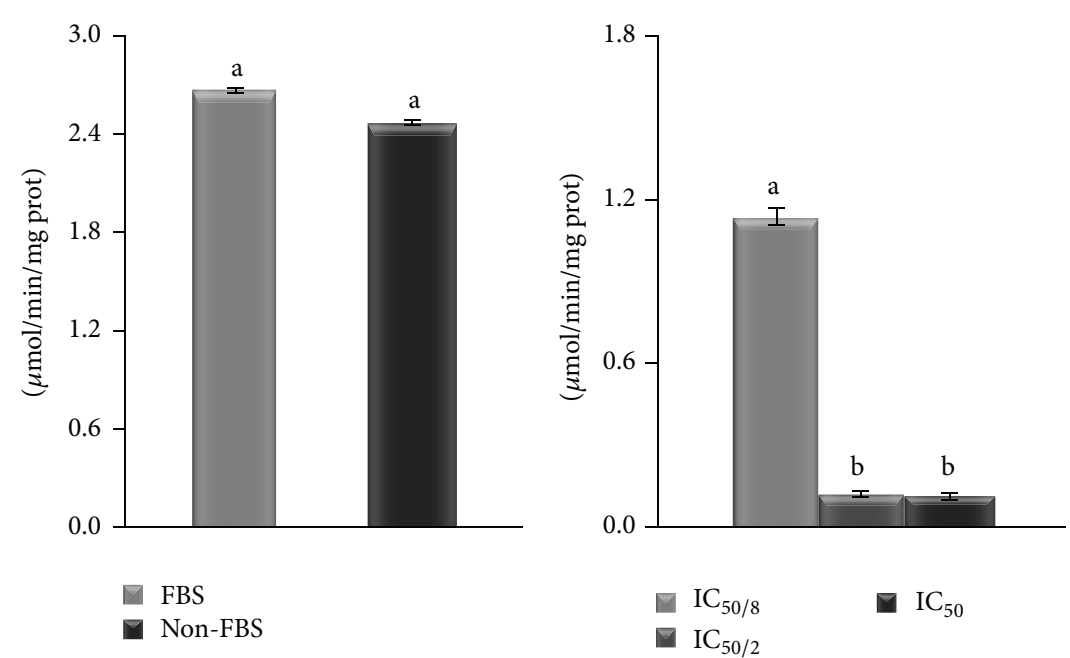

(a)

G6PDH activity
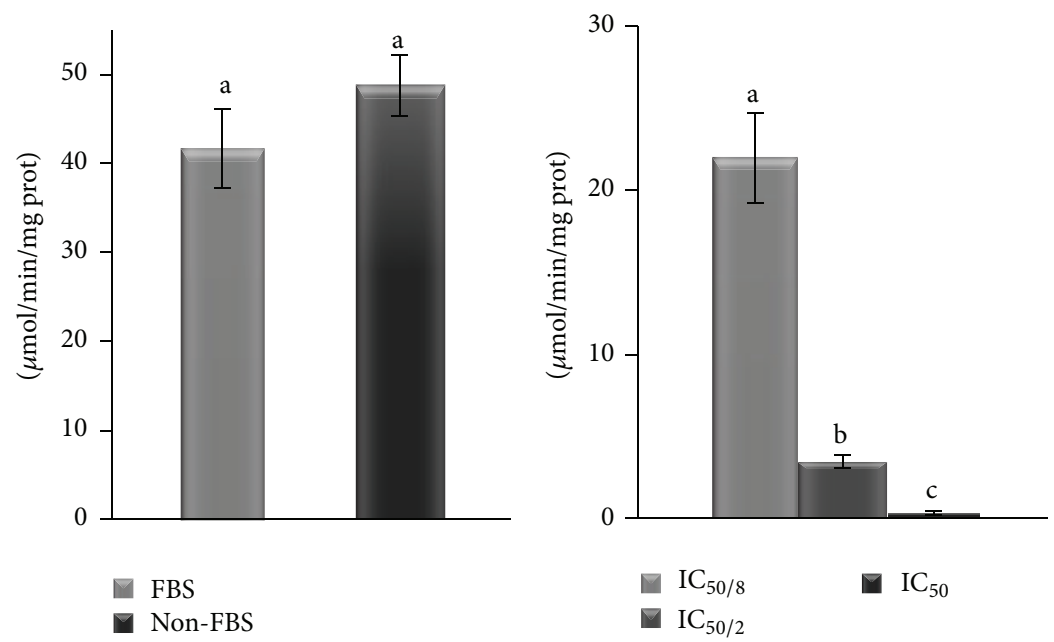

(b)

GST activity
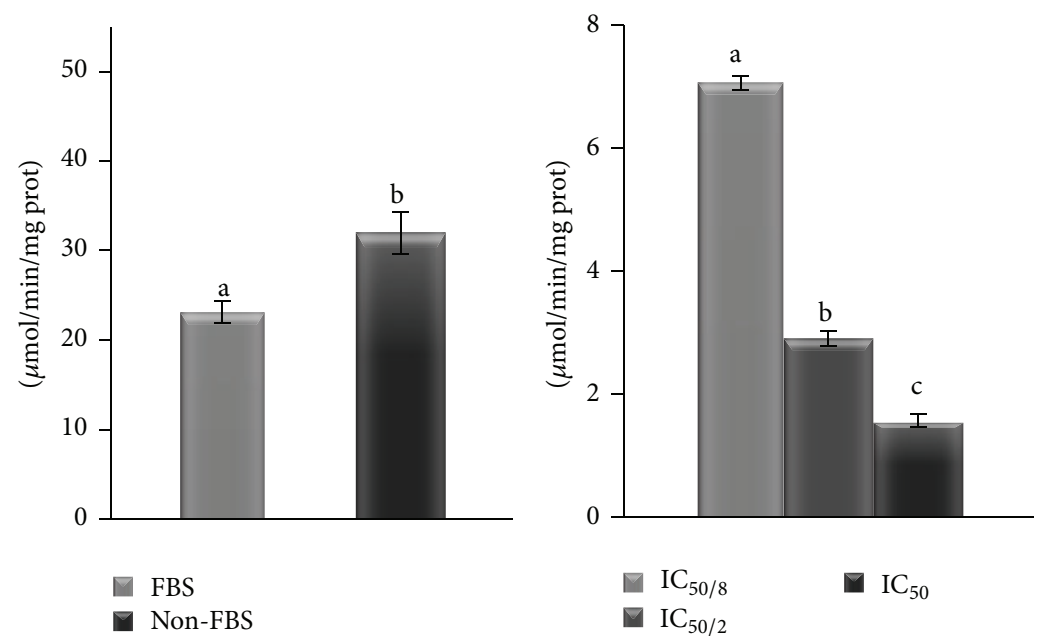

(c)

FIgURE 4: Continued. 


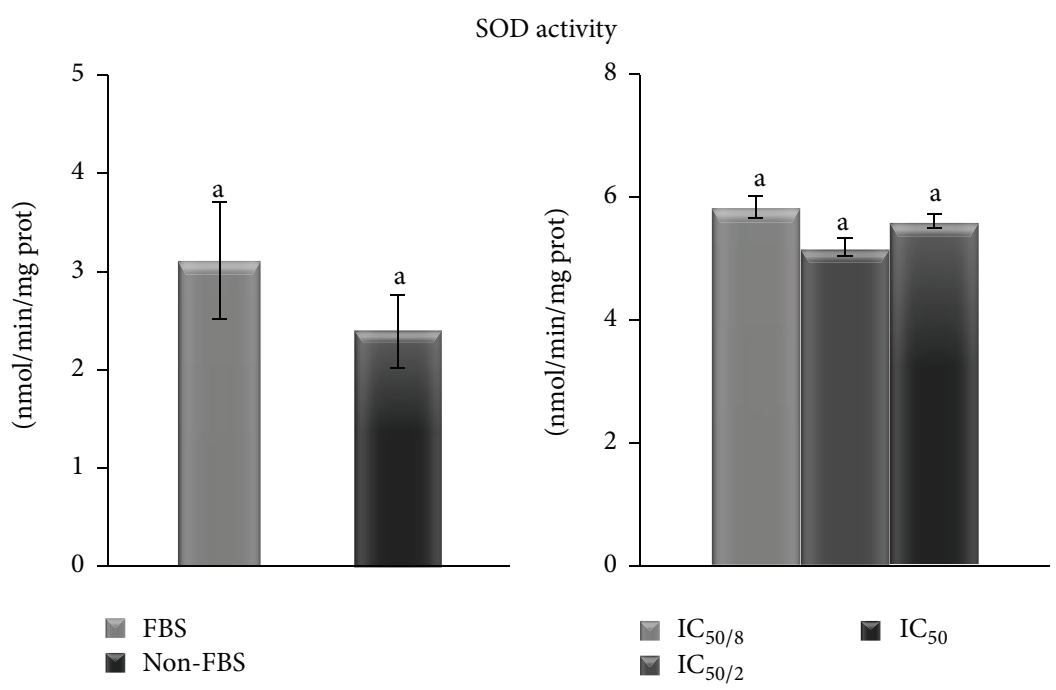

(d)

FIGURE 4: CAT (a), G6PDH (b), GST (c), and SOD (d) specific activities on B16F10 cells. On the left side, cells cultivated with and without FBS, and on the right side, cell cultivated without FBS and different MA dosages. Values are expressed as means \pm SD. Different letters indicate significant differences $(P<0.05)$.

oxidants [56]. Among other biological properties of NADPH, it has been demonstrated that it protects CAT from inactivation [57-59] and plays a crucial role in maintaining the redox state of the cell through GSH regeneration from GSSG. Low NADPH levels due to the imbalance in the cellular homeostasis could be, partially, responsible for the low activity levels observed in CAT and GST enzyme activities. All these results are in accordance with DHR 123 assay.

3.4. Validation by Western Blot. To corroborate the effect of different MA levels in cells without FBS in the antioxidant enzymes measured, an immune-blotting analysis was carried out to confirm the differential expression of same specific enzymes: CAT, G6PDH, GST, and SOD (Figure 5), under the same experimental condition (MA levels without FBS). Results obtained of immune-blotting analysis agree with those in the enzyme analysis, tending to decrease their activity and expression as MA concentration increases without FBS, although this pattern is not statistically significant in all enzymes.

\section{Conclusions}

It has been described in the scientific literature that triterpenes and polyphenols, in physiological doses, are able to improve the intrinsic cell tolerance against oxidative stress by increasing the antioxidant potential and modulation related to proliferation/survival in cell cultures and experimentation animals. However, at supraphysiological doses, these compounds appear to induce programmed death via the activation of signals involved in apoptosis and inhibition of proliferation proteins associated with survival/cell death. This indicates that the experimental conditions (concentrations, culture conditions, cell type, duration of the treatment, etc.) have to be seriously considered as they may determine the biological activity of these natural compounds. As it is difficult to predict their effect, there is a need to understand their molecular mechanisms of action in each context. Results obtained in this paper must be considered in these experimental conditions.

\section{Conflict of Interests}

Amalia Pérez-Jiménez declares having a research contract with the company Biomaslinic S.L., which owns part of the rights of international patents related to the extraction and exploitation of maslinic acid and hydroxytyrosol from different natural sources. The rest of the authors declare that there is no conflict of interests to disclose.

\section{Authors' Contribution}

Eva E. Rufino-Palomares, Fernando J. Reyes-Zurita, and José A. Lupiáñez were responsible for conception and design of the work. Eva E. Rufino-Palomares, Khalida Mokhtari, Celeny Figuera, Amalia Pérez-Jiménez, Fernando J. ReyesZurita, Leticia García-Salguero, Pedro P. Medina, Juan Peragón, and José A. Lupiáñez performed data acquisition and compilation. Eva E. Rufino-Palomares, Khalida Mokhtari, Celeny Figuera, and Pedro P. Medina performed cell viability experiments. Eva E. Rufino-Palomares, Khalida Mokhtari, Celeny Figuera, and Leticia García-Salguero were responsible for rhodamine 123 fluorescence. Eva E. RufinoPalomares, Khalida Mokhtari, Celeny Figuera, Amalia PérezJiménez, Leticia García-Salguero, and Fernando J. ReyesZurita were responsible for enzymes activities. Eva E. RufinoPalomares, Khalida Mokhtari, Celeny Figuera, Amalia PérezJiménez, Leticia García-Salguero, Fernando J. Reyes-Zurita, Pedro P. Medina, and Juan Peragón performed Western 

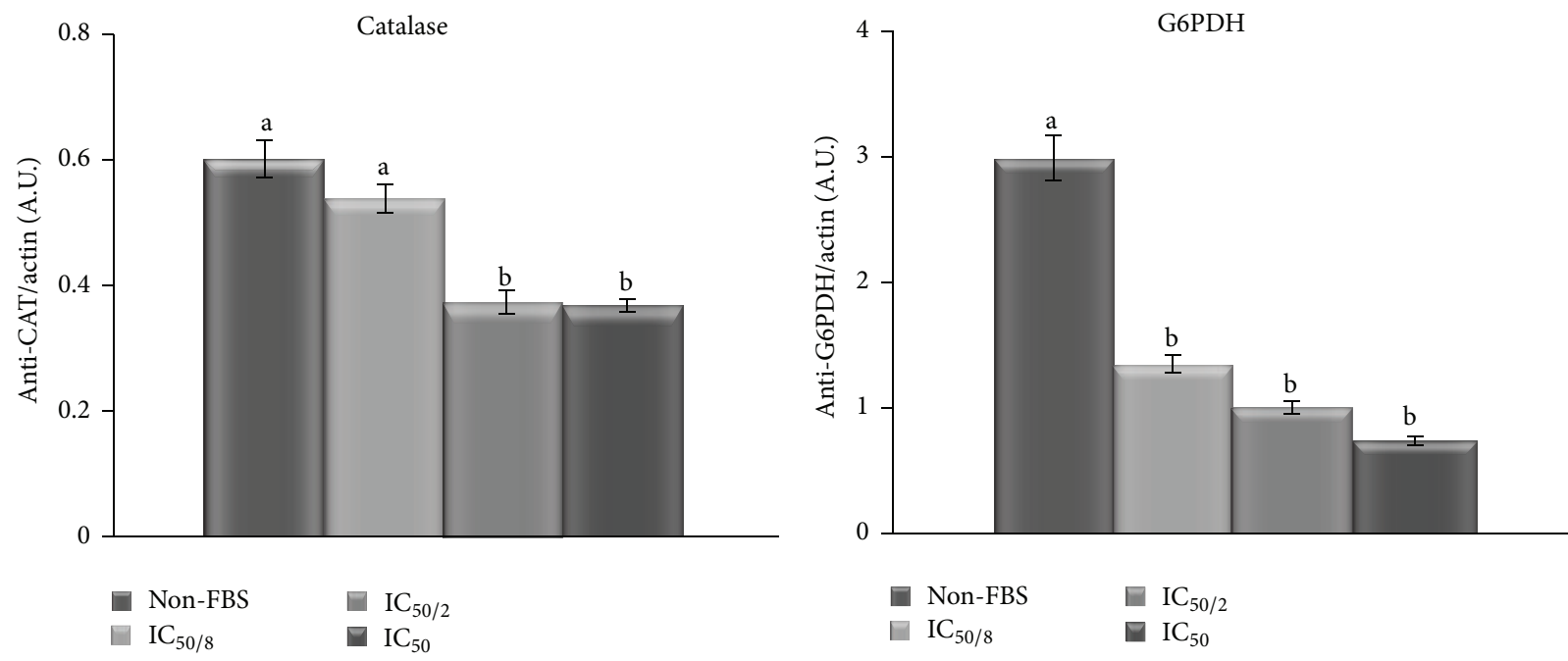

\begin{abstract}
Catalase
\end{abstract}

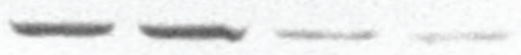

Actin

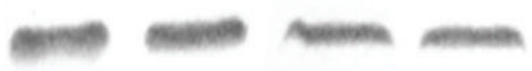

(a)

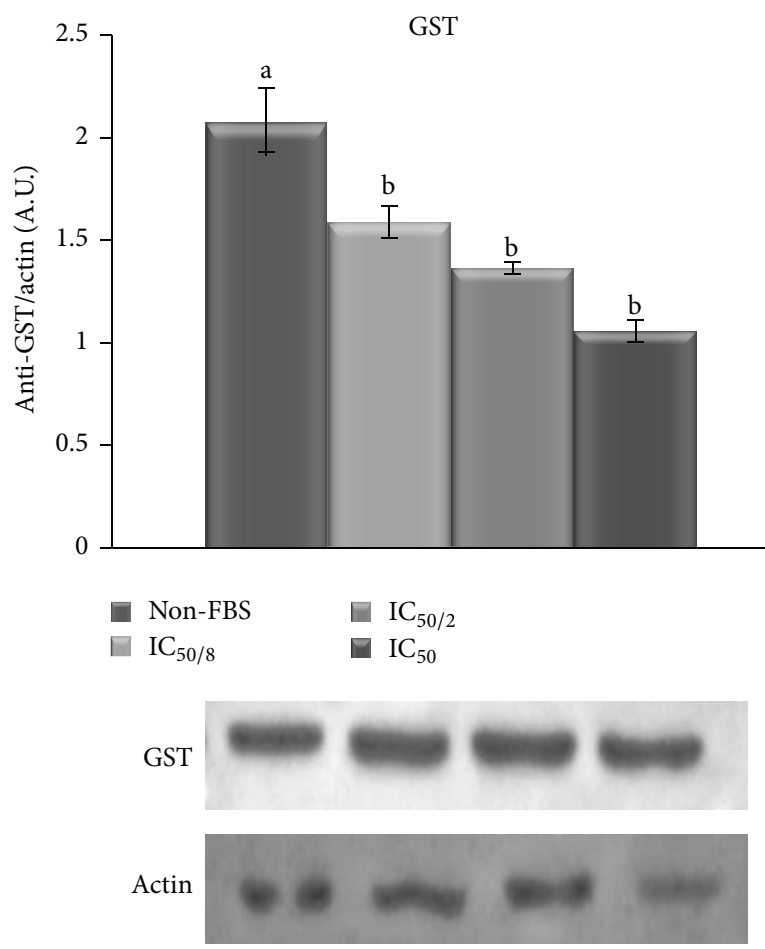

(c)

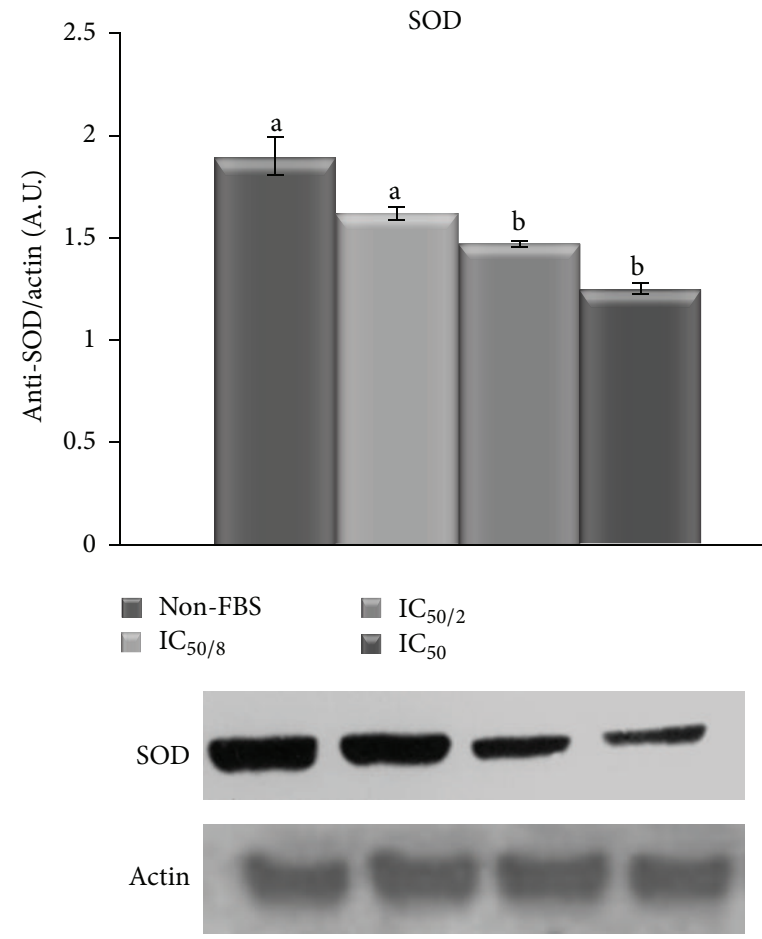

(d)

FIGURE 5: Western blots of CAT (a), G6PDH (b), GST (c), and SOD (d) on B16F10 cells cultivated without FBS at different MA dosages. The levels of specific protein expression are shown as arbitrary intensity units of each band compared to arbitrary intensity units of actin. Values are expressed as means \pm SD. Different letters indicate significant differences $(P<0.05)$. 
blotting assays. Eva E. Rufino-Palomares, Amalia PérezJiménez, Fernando J. Reyes-Zurita, Leticia García-Salguero, Khalida Mokhtari, Pedro P. Medina, Juan Peragón, and José A. Lupiáñez wrote and revised the paper. Eva E. RufinoPalomares, Amalia Pérez-Jiménez, and José A. Lupiáñez were responsible for general coordination of writing. All authors have read and approved the final version of the paper. Khalida Mokhtari and Eva E. Rufino-Palomares have contributed equally to this work.

\section{Acknowledgments}

This study has been supported, in part, by funds of the consolidated Research Group BIO-157, from the General Secretariat of Universities, Research and Technology of the Ministry of Economy, Innovation, Science and Employment Government of the Junta de Andalucía (Spain), and by the Research Contract no. C-3650-00 under the program FEDER-INNTERCONECTA from the Spanish Government and European Union FEDER funds. Amalia Pérez-Jiménez is a recipient of a postdoctoral research fellowship TorresQuevedo no. PTQ 12-05739.

\section{References}

[1] A. P. Pereira, I. C. F. R. Ferreira, F. Marcelino et al., "Phenolic compounds and antimicrobial activity of olive (Olea europaea L. Cv. Cobrançosa) leaves," Molecules, vol. 12, no. 5, pp. 11531162, 2007.

[2] H.-X. Xu, F.-Q. Zeng, M. Wan, and K.-Y. Sim, "Anti-HIV triterpene acids from Geum japonicum," Journal of Natural Products, vol. 59, no. 7, pp. 643-645, 1996.

[3] R. Rodriguez-Rodriguez, J. S. Perona, M. D. Herrera, and V. Ruiz-Gutierrez, "Triterpenic compounds from 'Orujo' olive oil elicit vasorelaxation in aorta from spontaneously hypertensive rats," Journal of Agricultural and Food Chemistry, vol. 54, no. 6, pp. 2096-2102, 2006.

[4] F. A. Aladedunye, D. A. Okorie, and O. M. Ighodaro, "Antiinflammatory and antioxidant activities and constituents of Platostoma africanum P. Beauv," Natural Product Research, vol. 22, no. 12, pp. 1067-1073, 2008.

[5] A. Braca, I. Morelli, J. Méndez, L. Battinelli, L. Braghiroli, and G. Mazzanti, "Antimicrobial triterpenoids from Licania heteromorpha," Planta Medica, vol. 66, no. 8, pp. 768-769, 2000.

[6] A. Parra, S. Martin-Fonseca, F. Rivas et al., "Solid-phase library synthesis of bi-functional derivatives of oleanolic and maslinic acids and their cytotoxicity on three cancer cell lines," ACS Combinatorial Science, vol. 16, no. 8, pp. 428-447, 2014.

[7] F. J. Reyes-Zurita, E. E. Rufino-Palomares, P. P. Medina et al., "Antitumour activity on extrinsic apoptotic targets of the triterpenoid maslinic acid in p53-deficient Caco-2 adenocarcinoma cells," Biochimie, vol. 95, no. 11, pp. 2157-2167, 2013.

[8] E. E. Rufino-Palomares, F. J. Reyes-Zurita, L. García-Salguero et al., "Maslinic acid, a triterpenic anti-tumoural agent, interferes with cytoskeleton protein expression in HT29 human coloncancer cells," Journal of Proteomics, vol. 83, pp. 15-25, 2013.

[9] S. Sánchez-Tena, F. J. Reyes-Zurita, S. Díaz-Moralli et al., "Maslinic acid-enriched diet decreases intestinal tumorigenesis in $\mathrm{Apc}^{\mathrm{Min} /+}$ mice through transcriptomic and metabolomic reprogramming," PLoS ONE, vol. 8, no. 3, Article ID e59392, 2013.
[10] F. J. Reyes-Zurita, E. E. Rufino-Palomares, J. A. Lupiáñez, and M. Cascante, "Maslinic acid, a natural triterpene from Olea europaea L., induces apoptosis in HT29 human colon-cancer cells via the mitochondrial apoptotic pathway," Cancer Letters, vol. 273, no. 1, pp. 44-54, 2009.

[11] R. Martín, J. Carvalho, E. Ibeas, M. Hernández, V. RuizGutierrez, and M. L. Nieto, "Acidic triterpenes compromise growth and survival of astrocytoma cell lines by regulating reactive oxygen species accumulation," Cancer Research, vol. 67, no. 8, pp. 3741-3751, 2007.

[12] F. J. Reyes, J. J. Centelles, J. A. Lupiáñez, and M. Cascante, " $(2 \alpha, 3 \beta)-2,3$-Dihydroxyolean-12-en-28-oic acid, a new natural triterpene from Olea europea, induces caspase dependent apoptosis selectively in colon adenocarcinoma cells," FEBS Letters, vol. 580, no. 27, pp. 6302-6310, 2006.

[13] X. Wen, H. Sun, J. Liu et al., "Naturally occurring pentacyclic triterpenes as inhibitors of glycogen phosphorylase: synthesis, structure-activity relationships, and X-ray crystallographic studies," Journal of Medicinal Chemistry, vol. 51, no. 12, pp. 35403554, 2008.

[14] X. Wen, H. Sun, J. Liu et al., "Pentacyclic triterpenes. Part 1: the first examples of naturally occurring pentacyclic triterpenes as a new class of inhibitors of glycogen phosphorylases," Bioorganic \& Medicinal Chemistry Letters, vol. 15, no. 22, pp. 4944-4948, 2005.

[15] X. Wen, P. Zhang, J. Liu et al., "Pentacyclic triterpenes. Part 2. Synthesis and biological evaluation of maslinic acid derivatives as glycogen phosphorylase inhibitors," Bioorganic and Medicinal Chemistry Letters, vol. 16, no. 3, pp. 722-726, 2006.

[16] J. Liu, H. Sun, W. Duan, D. Mu, and L. Zhang, "Maslinic acid reduces blood glucose in KK-Ay mice," Biological \& Pharmaceutical Bulletin, vol. 30, no. 11, pp. 2075-2078, 2007.

[17] M. Fernández-Navarro, J. Peragón, V. Amores, M. de la Higuera, and J. A. Lupiáñez, "Maslinic acid added to the diet increases growth and protein-turnover rates in the white muscle of rainbow trout (Oncorhynchus mykiss)," Comparative Biochemistry and Physiology C: Toxicology and Pharmacology, vol. 147, no. 2, pp. 158-167, 2008.

[18] M. Fernández-Navarro, J. Peragón, F. J. Esteban, M. de la Higuera, and J. A. Lupiáñez, "Maslinic acid as a feed additive to stimulate growth and hepatic protein-turnover rates in rainbow trout (Onchorhynchus mykiss)," Comparative Biochemistry and Physiology Part C: Toxicology \& Pharmacology, vol. 144, no. 2, pp. 130-140, 2006.

[19] E. E. Rufino-Palomares, F. J. Reyes-Zurita, L. García-Salguero, J. Peragón, M. de la Higuera, and J. A. Lupiáñez, “The role of maslinic acid in the pentose phosphate pathway during growth of gilthead sea bream (Sparus aurata)," Aquaculture Nutrition, vol. 19, no. 5, pp. 709-720, 2013.

[20] E. E. Rufino-Palomares, F. J. Reyes-Zurita, L. García-Salguero, J. Peragón, M. De La Higuera, and J. A. Lupiañez, "Maslinic acid, a natural triterpene, and ration size increased growth and protein turnover of white muscle in gilthead sea bream (Sparus aurata)," Aquaculture Nutrition, vol. 18, no. 5, pp. 568-580, 2012.

[21] E. E. Rufino-Palomares, F. J. Reyes-Zurita, L. García-Salguero, J. Peragón, M. De La Higuera, and J. A. Lupiáñez, "Maslinic acid and ration size enhanced hepatic protein-turnover rates of gilthead sea bream (Sparus aurata)," Aquaculture Nutrition, vol. 18, no. 2, pp. 138-151, 2012.

[22] A. Abdal Dayem, H.-Y. Choi, J.-H. Kim, and S.-G. Cho, "Role of oxidative stress in stem, cancer, and cancer stem cells," Cancers, vol. 2, no. 2, pp. 859-884, 2010. 
[23] M. Kirsch and H. de Groot, "NAD(P)H, a directly operating antioxidant?" The FASEB Journal, vol. 15, no. 9, pp. 1569-1574, 2001.

[24] N. Ogasawara, T. Oguro, T. Sakabe et al., "Hemoglobin induces the expression of indoleamine 2,3-dioxygenase in dendritic cells through the activation of PI3K, PKC, and NF- $\kappa \mathrm{B}$ and the generation of reactive oxygen species," Journal of Cellular Biochemistry, vol. 108, no. 3, pp. 716-725, 2009.

[25] G. Waris and H. Ahsan, "Reactive oxygen species: role in the development of cancer and various chronic conditions," Journal of Carcinogenesis, vol. 5, article 14, 2006.

[26] P. Storz, "Targeting the alternative NF- $\kappa$ B pathway in pancreatic cancer: a new direction for therapy?" Expert Review of Anticancer Therapy, vol. 13, no. 5, pp. 501-504, 2013.

[27] Z.-L. Chu, F. Pio, Z. Xie et al., "A novel enhancer of the Apaf1 apoptosome involved in cytochrome $c$-dependent caspase activation and apoptosis," The Journal of Biological Chemistry, vol. 276, no. 12, pp. 9239-9245, 2001.

[28] J. H. Kim, J. O. Lee, S. K. Lee et al., "Celastrol suppresses breast cancer MCF-7 cell viability via the AMP-activated protein kinase (AMPK)-induced p53-polo like kinase 2 (PLK-2) pathway," Cellular Signalling, vol. 25, no. 4, pp. 805-813, 2013.

[29] J.-H. Lee, Y.-S. Won, K.-H. Park et al., "Celastrol inhibits growth and induces apoptotic cell death in melanoma cells via the activation ROS-dependent mitochondrial pathway and the suppression of PI3K/AKT signaling," Apoptosis, vol. 17, no. 12, pp. 1275-1286, 2012.

[30] M. H. Massaoka, A. L. Matsuo, C. R. Figueiredo et al., "Jacaranone induces apoptosis in melanoma cells via ROS-mediated downregulation of akt and p38 MAPK activation and displays antitumor activity in vivo," PLoS ONE, vol. 7, no. 6, Article ID e38698, 2012.

[31] T. Mosmann, "Rapid colorimetric assay for cellular growth and survival: application to proliferation and cytotoxicity assays," Journal of Immunological Methods, vol. 65, no. 1-2, pp. 55-63, 1983.

[32] J. M. McCord and I. Fridovich, "Superoxide dismutase. An enzymic function for erythrocuprein (hemocuprein)," The Journal of Biological Chemistry, vol. 244, no. 22, pp. 6049-6055, 1969.

[33] H. Aebi, "[13] Catalase in vitro," Methods in Enzymology, vol. 105, pp. 121-126, 1984.

[34] J. A. Lupiañez, F.-J. Adroher, A. M. Vargas, and A. Osuna, "Differential behaviour of glucose 6-phosphate dehydrogenase in two morphological forms of Trypanosoma cruzi," International Journal of Biochemistry, vol. 19, no. 11, pp. 1085-1089, 1987.

[35] J. Peragón, F. Aranda, L. García-Salguero, F. J. Corpas, and J. A. Lupiáñez, "Stimulation of rat-kidney hexose monophosphate shunt dehydrogenase activity by chronic metabolic acidosis," Biochemistry International, vol. 18, no. 5, pp. 1041-1050, 1989.

[36] W. H. Habig, M. J. Pabst, and W. B. Jakoby, "Glutathione $S$ transferases. The first enzymatic step in mercapturic acid formation," The Journal of Biological Chemistry, vol. 249, no. 22, pp. 7130-7139, 1974.

[37] R. Khammanit, S. Chantakru, Y. Kitiyanant, and J. Saikhun, "Effect of serum starvation and chemical inhibitors on cell cycle synchronization of canine dermal fibroblasts," Theriogenology, vol. 70, no. 1, pp. 27-34, 2008.

[38] H. S. Gatehouse, J. Poulton, N. P. Markwick et al., "Changes in gene expression in the permissive larval host light brown apple moth (Epiphyas postvittana, Tortricidae) in response to EppoNPV (Baculoviridae) infection," Insect Molecular Biology, vol. 18, no. 5, pp. 635-648, 2009.
[39] D. Brunner, J. Frank, H. Appl, H. Schöffl, W. Pfaller, and G. Gstraunthaler, "Serum-free cell culture: the serum-free media interactive online database," ALTEX, vol. 27, no. 1, pp. 53-62, 2010.

[40] P. S. Leung and M. de Gasparo, "Involvement of the pancreatic renin-angiotensin system in insulin resistance and the metabolic syndrome," Journal of Cardiometabolic Syndrome, vol. 1, no. 3, pp. 197-203, 2006.

[41] S. Zhang, D. Ding, X. Zhang, L. Shan, and Z. Liu, "Maslinic acid induced apoptosis in bladder cancer cells through activating p38 MAPK signaling pathway," Molecular and Cellular Biochemistry, vol. 392, no. 1-2, pp. 281-287, 2014.

[42] G. Rothe, A. Oser, and G. Valet, "Dihydrorhodamine 123: a new flow cytometric indicator for respiratory burst activity in neutrophil granulocytes," Naturwissenschaften, vol. 75, no. 7, pp. 354-355, 1988.

[43] R. K. Emaus, R. Grunwald, and J. J. Lemasters, "Rhodamine 123 as a probe of transmembrane potential in isolated rat-liver mitochondria: spectral and metabolic properties," Biochimica et Biophysica Acta (BBA)-Bioenergetics, vol. 850, no. 3, pp. 436448, 1986.

[44] T. Lindl, Zell-und Gewebekultur, Spektrum Akademischer, Heidelberg, Germany, 5th edition, 2002.

[45] G. Gstraunthaler, T. Lindl, and J. van der Valk, "A plea to reduce or replace fetal bovine serum in cell culture media," Cytotechnology, vol. 65, no. 5, pp. 791-793, 2013.

[46] B. N. Mkhwanazi, M. R. Serumula, R. B. Myburg, F. R. Van Heerden, and C. T. Musabayane, "Antioxidant effects of maslinic acid in livers, hearts and kidneys of streptozotocin-induced diabetic rats: effects on kidney function," Renal Failure, vol. 36, no. 3, pp. 419-431, 2014.

[47] X. Qin, C. Qiu, and L. Zhao, "Maslinic acid protects vascular smooth muscle cells from oxidative stress through Akt/Nrf2/HO-1 pathway," Molecular and Cellular Biochemistry, vol. 390, no. 1-2, pp. 61-67, 2014.

[48] Y. Allouche, F. Warleta, M. Campos et al., "Antioxidant, antiproliferative, and pro-apoptotic capacities of pentacyclic triterpenes found in the skin of olives on MCF-7 human breast cancer cells and their effects on DNA damage," Journal of Agricultural \& Food Chemistry, vol. 59, no. 1, pp. 121-130, 2011.

[49] M. P. Montilla, A. Agil, M. C. Navarro et al., "Antioxidant activity of maslinic acid, a triterpene derivative obtained from Olea europaea," Planta Medica, vol. 69, no. 5, pp. 472-474, 2003.

[50] B. Siewert and R. Csuk, "Membrane damaging activity of a maslinic acid analog," European Journal of Medicinal Chemistry, vol. 74, pp. 1-6, 2014.

[51] B. Huang, J. Luo, Y. Han, S. Li, F. Liu, and L. Wu, "Protective effect of maslinic acid preconditioning against oxygenglucose deprivation-induced injuries in embryonic rat cortical neurons," Nan Fang Yi Ke Da Xue Xue Bao, vol. 33, no. 3, pp. 322-331, 2013.

[52] Y. Qian, T. Guan, X. Tang et al., "Maslinic acid, a natural triterpenoid compound from Olea europaea, protects cortical neurons against oxygen-glucose deprivation-induced injury," European Journal of Pharmacology, vol. 670, no. 1, pp. 148-153, 2011.

[53] S. V. V. Lakshmi, G. Padmaja, P. Kuppusamy, and V. K. Kutala, "Oxidative stress in cardiovascular disease," Indian Journal of Biochemistry \& Biophysics, vol. 46, no. 6, pp. 421-440, 2009.

[54] F. J. Reyes-Zurita, G. Pachón-Peña, D. Lizárraga, E. E. RufinoPalomares, M. Cascante, and J. A. Lupiáñez, "The natural triterpene maslinic acid induces apoptosis in HT29 colon cancer 
cells by a JNK-p53-dependent mechanism," BMC Cancer, vol. 11, article 154, 2011.

[55] W.-Y. Kuo, J.-Y. Lin, and T. K. Tang, "Human glucose-6phosphate dehydrogenase (G6PD) gene transforms NIH 3T3 cells and induces tumors in nude mice," International Journal of Cancer, vol. 85, no. 6, pp. 857-864, 2000.

[56] D. Bianchi, O. Bertrand, K. Haupt, and N. Coello, "Effect of gluconic acid as a secondary carbon source on non-growing Llysine producers cells of Corynebacterium glutamicum. Purification and properties of 6-phosphogluconate dehydrogenase," Enzyme and Microbial Technology, vol. 28, no. 9-10, pp. 754-759, 2001.

[57] I. Bañuelos-Vargas, L. M. López, A. Pérez-Jiménez, and H. Peres, "Effect of fishmeal replacement by soy protein concentrate with taurine supplementation on hepatic intermediary metabolism and antioxidant status of totoaba juveniles (Totoaba macdonaldi)," Comparative Biochemistry and Physiology BBiochemistry and Molecular Biology, vol. 170, no. 1, pp. 18-25, 2014.

[58] A. E. Morales, A. Pérez-Jiménez, M. C. Hidalgo, E. Abellán, and G. Cardenete, "Oxidative stress and antioxidant defenses after prolonged starvation in Dentex dentex liver," Comparative Biochemistry and Physiology Part C: Toxicology \& Pharmacology, vol. 139, no. 1-3, pp. 153-161, 2004.

[59] H. N. Kirkman, M. Rolfo, A. M. Ferraris, and G. F. Gaetani, "Mechanisms of protection of catalase by NADPH: kinetics and stoichiometry," The Journal of Biological Chemistry, vol. 274, no. 20, pp. 13908-13914, 1999. 


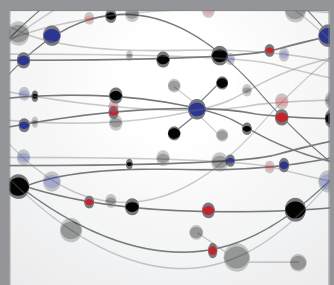

The Scientific World Journal
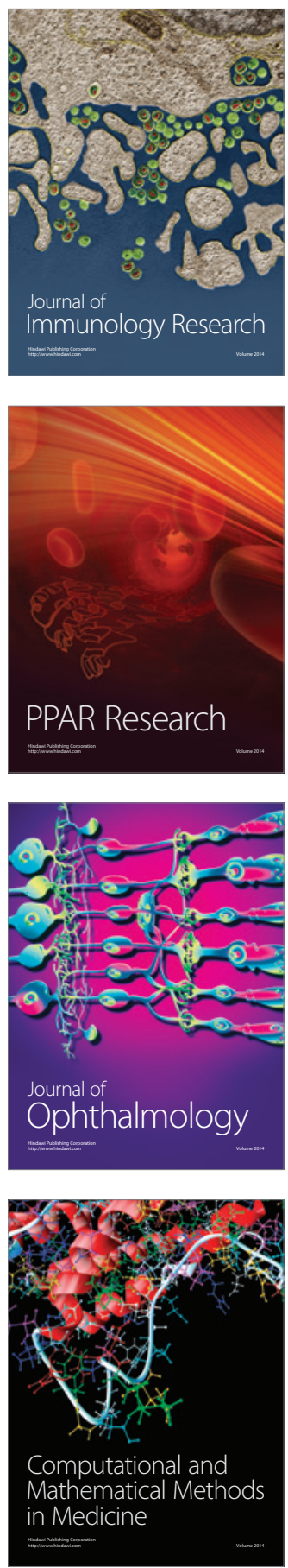

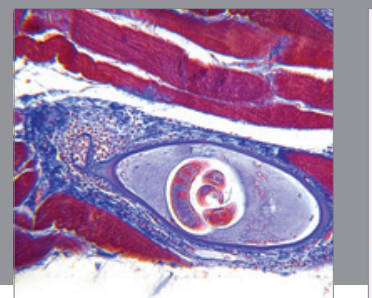

Gastroenterology

Research and Practice
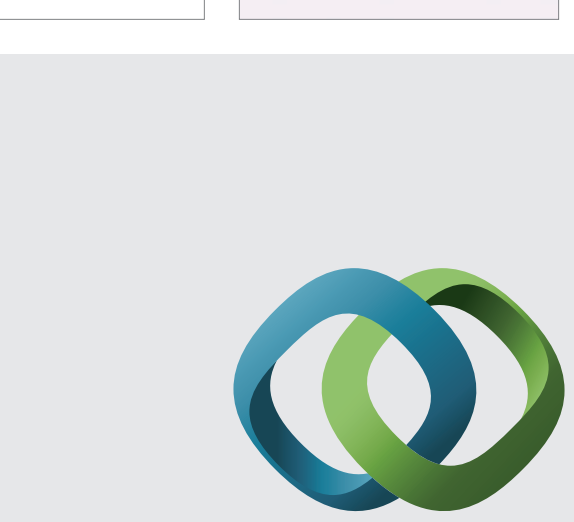

\section{Hindawi}

Submit your manuscripts at

http://www.hindawi.com
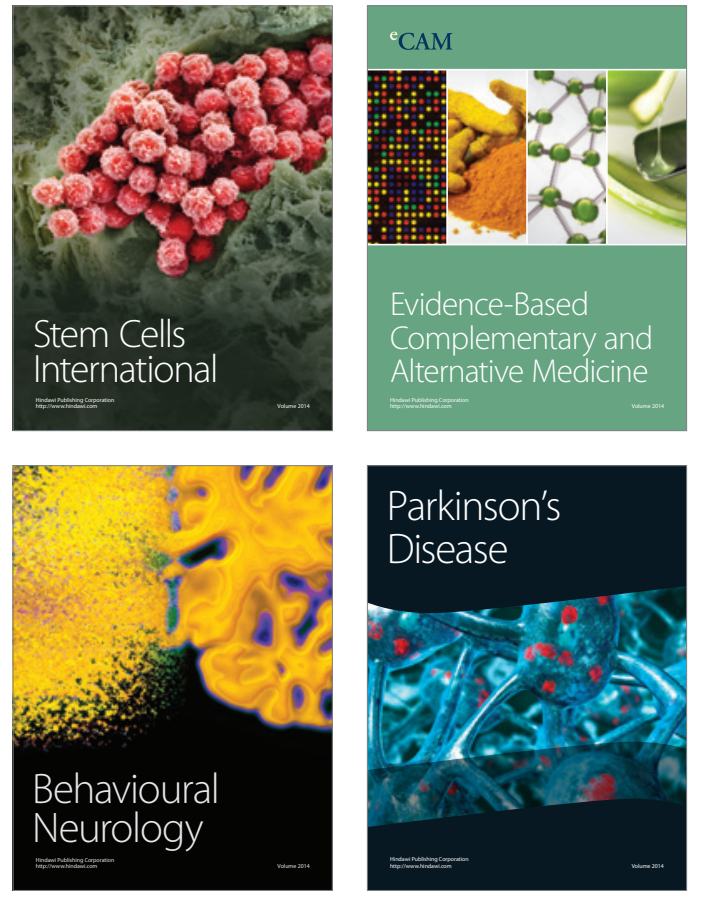
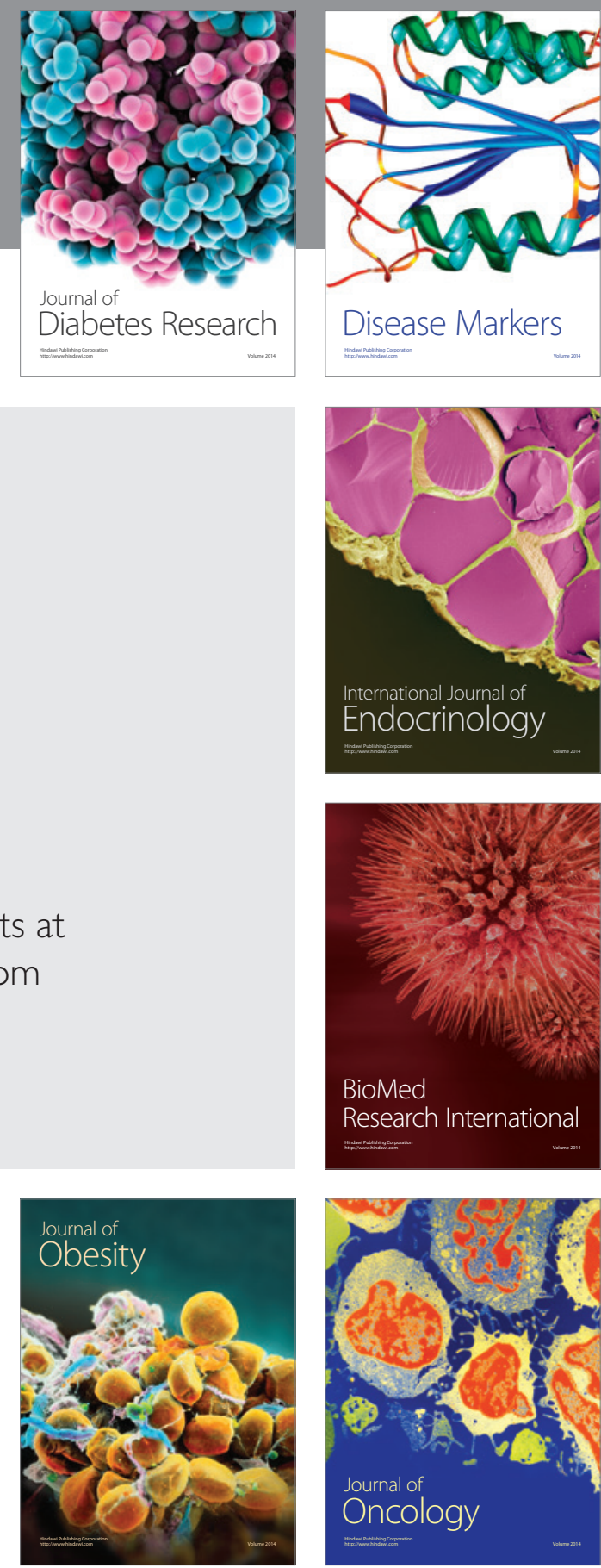

Disease Markers
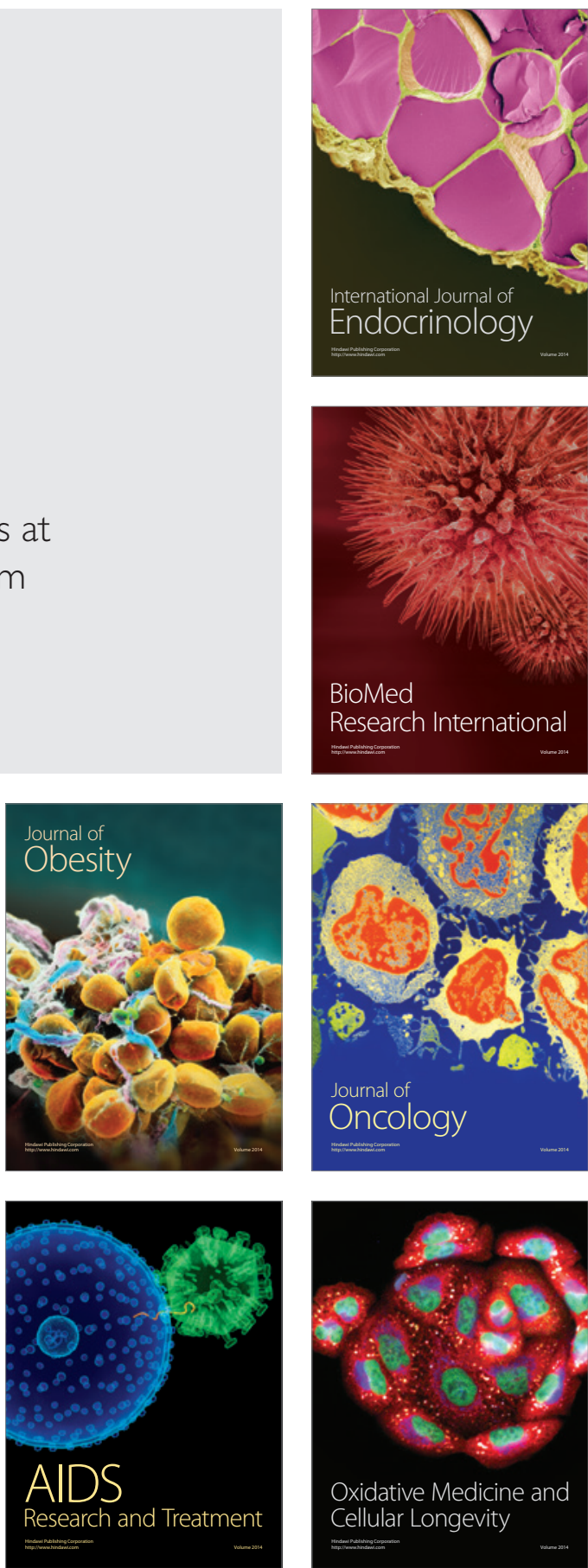